\title{
Egyptian Journal of Chemistry
}

\author{
http://ejchem.journals.ekb.eg/
}

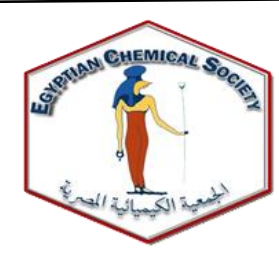

\section{Cellulases and Animal Feed Production by Solid State Fermentation by}

\section{Aspergillus fumigatus NRCF-122 mutant}

\author{
Mohamed Fadel ${ }^{\mathrm{a}}$, Ahmed A. Hamed ${ }^{\mathrm{a}}$, Ahmed M. Abd-Elaziz ${ }^{\mathrm{b}}$, Manal M.E. Ghanem ${ }^{\mathrm{b}}$, \\ Amira M. Roshdy ${ }^{a}$ \\ ${ }^{a}$ Microbial Chemistry Department, National Research Centre, Dokki, Giza. Egypt. \\ ${ }^{b}$ Molecular biology department. National Research Centre, Dokki, Giza. Egypt
}

\begin{abstract}
A high cellulase-producing fungus was isolated from agricultural waste compost, purified, identified genetically as Aspergillus fumigatus NRCF-122 (accession no. MT318341), and improved by UV-irradiation for cellulase production (named as A. fumigatus mutant-17). Optimal cellulase production conditions were studied using sugar beet pulp "SBP" as the substrate of solid-state fermentation "SSF" technique. The optimal conditions were: initial moisture content ratio (1:2 w/v), incubation temperature $\left(30^{\circ} \mathrm{C}\right)$, initial $\mathrm{pH}$ of solid culture (10), incubation period (4 days), aeration area $(1: 100$ ratio $((1 \%))$, SBP substrate weight : flask volume of moistened SBP in a $250 \mathrm{~mL}$ Erlenmeyer flask, fungal inoculum (seeding) culture age ( 3 days) and inoculum size $(20 \%, \mathrm{v} / \mathrm{w}$ ). Studies were also involved the effect of different nitrogen sources where urea is the best nitrogen source for cellulase production. Concerning the application of bioethanol production from yeast, using rice straw cellulose as a source of fermentable reducing sugars, the lingo-cellulosic waste rice straw was first pretreated (with $\mathrm{NaOH}$ $1.5 \%)$ to reduce crystallinity of cellulose \& removing lignin and other inhibitors, enhancing the subsequent process (saccharification) of rice straw cellulose. Then, its cellulose was saccharified enzymatically by cellulases (produced from SBP as substrate (under SSF condition) as substrate under the optimum conditions) resulting in reducing sugars. one of the largest livestock production operating costs is the feed bill. In our study we evaluated the resulted crude protein content of the fermented SBP and the results declared that, the total digest nutrient (TDN) and gross energy performance were increased, where as crude fiber, acid detergent fiber ADF \& neutral detergent fiber NDF were decreased, thereby upgrading the feed quality of biologically treated SBP.
\end{abstract}

Keywords: Cellulases; Animal feed production; solid-state fermentation; Aspergillus fumigatus NRCF-122

\section{Introduction}

Cellulose is the abundant and widespread biopolymers on Earth [1]. Cellulose is a waterinsoluble polysaccharide that is made up of glucose units linked by $\beta-1,4$ glycosidic linkages. These monomers of glucose can be professionally transformed numerous valuable chemicals through the commercially presented chemical processes or fermentation by microbes [2]. Recently, microorganisms have been served as a leading producers or catalyst to produce enzymes, food ingredients, vitamins, proteins, organic acids, antibiotics, and nutraceuticals [3-14]. The agroindustrial by-products can be used to produce commercially essential products as enzymes. Enzymes as cellulases have industrial significance and broadly used in a variety of applied industries, as well as textile, pulp \& paper, laundry \& detergent, food processing, agricultural industries, and bioethanol production [15].

Cellulases are inducible enzymes, which are synthesized by microorganisms throughout their growth on cellulosic supplies. A total cellulase scheme consists of three classes of enzymes: Initially the endo-glucanases (1,4- $\beta$-D-glucan-4glucanohydrolase; EC 3.2.1.4) attack the $\beta-1,4$ bonds in the cellulose molecule randomly, and cellobiohydrolases (1,4- $\beta$-D-glucan glucohydrolase; EC 3.2.1.74) hydrolyse cellobiose as the primary structure from the non-reducing end of the cellulose. Finally, $\quad \beta$-glucosidases $\quad(\beta$-D-glucoside glucohydrolase; EC 3.2.1.21) convert the cellobiose

*Corresponding author e-mail: ahmedshalbio@gmail.com.; (Ahmed A. Hamed).

Receive Date: 12 February 2021, Revise Date: 07 March 2021, Accept Date: 14 March 2021

DOI: 10.21608/EJCHEM.2021.62744.3347

(C2021 National Information and Documentation Center (NIDOC) 
to glucose. The enzymatic processes to hydrolyze cellulosic materials can be accomplished during a series of reactions with diverse enzymes. The production cost and reaction conditions of the correlated enzyme systems considerably influence the enzyme-based bioconversion technology application. Thus, many searches have been devoted to obtain new microorganisms for producing cellulolytic enzymes with greater efficiency and higher specific activity [16].

Different types of microbes produce the cellulase enzymes naturally, such as fungi and bacteria. The most intensively studied and used for cellulase production on commercial scale fungi Trichoderma spp. and bacteria Bacillus spp. [2]. Many of fungi and bacteria able to utilize cellulose as a carbon source were identified. Many reports were studied cellulases produced by fungi, such as Aspergillus, Rhizopus, and Trichoderma species [16]. Strain improvement is generally achieved by inducing the random mutation in the microbe through mutagenesis via physical mutagens (e.g., UV-rays, Xrays, f-rays, etc.), or/and chemical mutagens (e.g., ethyl methane sulfonate "EMS", nitro-glycerine, etc.).

Lignocellulosic biomass contains cellulose, hemicellulose, lignin, and ash mixed in a complex structure. The pre-treatment reduces the crystallinity of cellulose, while removing lignin and other inhibitors, thereby enabling its enzymatic degradation. On the other hand, the pre-treatment may increase the surface area of the cellulose thereby improving its reactivity with the enzyme and thus its transformation.

Enzymatic hydrolysis of cellulose to the monomer soluble sugars makes it accessible as a feedstock for alcoholic fermentation, production of single cell protein, and other industrial processes. The cellulosic biomass utilization for ethanol production is a subject of worldwide attention in view of quick exhaustion of oil reserves and food shortages [17].

The cellulase production using fungi by solid-state fermentation (SSF) consider as one of the most attractive and cost-effective techniques. SSF is an old technique that has been emphasized to be efficient in the production of hydrolytic enzymes in which the cultivating conditions of the fungi simulate the ordinary environment. The choice of the substrate for SSF process, which can ease the anchorage of fungi, along with given that enough nutrients, still a subject of passionate research for several decades. The use of rice straw as a carbon source to produce cellulase as an alternative of using the refined cellulosic carbon source can reduce the whole cost of the enzyme and increases its cost-effective viability. The conditions of the fermentation processes have a vital result on the growth of the microorganisms and their released metabolic yield plus the expenditure of the production process. For multivariable processes, statistical optimization is valuable to save time and effort, reduce the required experiments, and accordingly, reduce the whole cost of the process. Response surface methodology in the past few years has been applied in the optimization processes in different microbiological and biotechnological fields. It has been effectively applied in the optimization of the microbial production of cellulase [18].

In this study, one strain with high production of cellulase was isolated from agricultural wastes compost and was identified by the $18 \mathrm{~S}$ rRNA sequence as Aspergillus fumigatus NRCF-122 and improved by UV-irradiation for cellulase production. Moreover, the optimal conditions for the maximum enzyme production were studied. In addition, an application of cellulase produced under SSF by $A$. fumigatus NRCF-122 was carried out in saccharification and animal feed production.

\section{Experimental}

\subsection{Isolation and identification of fungal isolate} using $18 \mathrm{~S}$ rDNA

The fungal strain was isolated from the compost of agricultural wastes and identified genetically by extraction of DNA and sequencing of the 18S rRNA gene. The extraction of the genomic DNA was performed using Qiagen DNeasy Mini Kit following the manufacturer's manual. The PCR reaction mixture was as follows: $\{1 \mu \mathrm{g}$ genomic DNA, $1 \mu \mathrm{L}$ (20 $\mathrm{uM}$ of each primer), $10 \mathrm{mM}$ dNTPs mixture, 2 units of Taq DNA polymerase enzyme and $10 \mu \mathrm{L} 5 \mathrm{X}$ reaction buffer\}. The amplification reactions were performed using two primers ITS1 TCCGTAGGTGAACCTGCG-3`)/ ITS4 (5`TCCTCCGCTTATTG ATATGC-3`) the following PCR thermal profiles: denaturation step at $94^{\circ} \mathrm{C}$ for 5 min followed by 35 cycles of $94^{\circ} \mathrm{C}$ for $30 \mathrm{sec}$, $55^{\circ} \mathrm{C}$ for $30 \mathrm{sec} ., 72^{\circ} \mathrm{C}$ for $90 \mathrm{sec}$, and a final extension step of $72^{\circ} \mathrm{C}$ for $5 \mathrm{~min}$. The amplified products were examined by electrophoresis and sequenced in Macrogen Companies, South Korea. The sequence produced was analyzed by using BLASTN program, to study the similarity and homology of the $18 \mathrm{~S}$ rRNA gene sequences with the similar existing sequences available at NCBI database.

\subsection{Sugar Beet Pulp (SBP) and sugar cane} molasses.

Sugar beet pulp (SBP), a by-product of beet sugar industry, was obtained from Abo-Korkas Sugar Factory, El-Minia, Egypt. 


\subsection{Mutation of wild type by $U V$ irradiation.}

Dilutions of mother fungal isolate suspension obtained from fungal culture on potato dextrose agar (PDA) slants after 3 days incubation at $30^{\circ} \mathrm{C}$ crushed in $10 \mathrm{ml}$ sterilized water then introduced in $100 \mathrm{ml}$ capacity conical flask, and diluted to be $10^{6-7}$ spores $/ \mathrm{ml}$. After, distributed into $9 \mathrm{~cm}$ diameter sterilized Petri dishes occupied by $4 \mathrm{ml}$ from above culture spores. These were exposed to UV radiations for different times ranging from 20 to 120 minutes in UV chamber keeping the distance of UV source at $15 \mathrm{~cm}$. After UV radiation, they were kept in dark for stabilization. Parent type and UV treated fungal spore suspensions of $0.1 \mathrm{ml}$ was inoculated into $5 \mathrm{~cm}$ diameter Petri plate containing PDA medium and incubated at $30^{\circ} \mathrm{C}$. After $96 \mathrm{hrs}$, the fungal growth was crushed in $10 \mathrm{ml}$ sterilized water and used as inoculum.

\subsection{Solid state fermentation (SSF) using sugar} beet pulp (SBP) as Substrate.

The experiments were carried out in $250 \mathrm{ml}$ Erlenmeyer flask containing $5 \mathrm{~g}$ of SBP moistened with distilled water at solid: liquid ratio $1: 2$ and sterilized for $15 \mathrm{~min}$ at $121^{\circ} \mathrm{C}$. After cooling, the flasks were inoculated with tested culture and incubated at $30^{\circ} \mathrm{C}$ for 4 days.

\subsection{Optimization of cellulase production under SSF cultivation condition using SBP as substrate.}

The optimization of physico-chemical parameters was done to reach the maximal production of cellulase by the selected mutant of A. fumigatus NRCF-122 (mutant-17). These parameters were the moisture content $(50-80 \% \mathrm{v} / \mathrm{w}$, where $\mathrm{v}$ and $\mathrm{w}$ represent water and (water + dried-SBP), respectively), incubation temperature $\left(24-36^{\circ} \mathrm{C}\right), \mathrm{pH}$ of solid culture (3-12), incubation time (2-7 days), aeration area $(2.5-10 \mathrm{~g})$ of moistened SBP in a $250 \mathrm{~mL}$ Erlenmeyer flask, age of inoculum (2-4 days), and inoculum size $(20-80 \%, \mathrm{v} / \mathrm{w})$. Studies were also involved the effect of nitrogen sources i.e. (urea, ammonium sulfate, di-ammonium phosphate and $\mathrm{NH}_{4} \mathrm{NO}_{3} \% \mathrm{w} / \mathrm{w}$ ).

Experiment was carried out at $30^{\circ} \mathrm{C}$ for 4 days with SBP initial solid; liquid ratio $1: 2$, which was inoculated with $20 \%(\mathrm{v} / \mathrm{w})$ of a 4-day-old seeding culture. Each experiment was performed in triplicates.

\subsection{Extraction of crude cellulases.}

The moldy SBP developed after 4 days of fermentation was mixed with distilled water at a 1:20 $(w / v)$ ratio. The mixture was shaken at $30^{\circ} \mathrm{C}$ for 30 minutes in an orbital shaker operating at $140 \mathrm{rpm}$.
The supernatant obtained by filtration was used as crude enzyme.

\subsection{Enzymes assay}

Exoglucanase (FPase): Exoglucanase (Filter paperase) activity was estimated according to the method described by Bai et al. [19]. Briefly, $1.3 \mathrm{ml}$ of $0.05 \mathrm{M}$ phosphate buffer, $(\mathrm{pH} 7)$ and $1 \times 6 \mathrm{~cm}$ filter paper followed by addition of $0.2 \mathrm{ml}$ of diluted cellulase was incubated at $40^{\circ} \mathrm{C}$ for $10 \mathrm{~min}$. Then the reaction was stopped by addition of $1.5 \mathrm{ml}$ dinitrosalicylic acid (DNS) reagent [20]. All reactions were boiled for $5 \mathrm{~min}$ and finally diluted with $2 \mathrm{ml}$ of $\mathrm{H}_{2} \mathrm{O}$. The absorbance at $540 \mathrm{~nm}$ was measured. One unit of cellulase activity was defined as the amount of enzyme releasing $1 \mu$ mole of reducing sugar from filter paper (FPU) per ml per $\min$.

Endogluganse (CMCase): Endogluganse (Carboxy Methyl Cellulase "CMCase") was determined according to [21]. The reaction mixture containing 1 $\mathrm{mL}$ of $1 \%$ carboxymethyl cellulose "CMC" in $0.5 \mathrm{M}$ phosphate buffer (pH 7.0) and $0.5 \mathrm{~mL}$ crude enzyme filtrate. The reducing sugar produced, after incubated at $40^{\circ} \mathrm{C}$ for $10 \mathrm{~min}$, was determined according to [20]. The absorbance of released sugars was determined at $540 \mathrm{~nm}$. One unit (IU) of CMCase activity was defined as the amount of enzyme releasing $1 \mu$ mole of reducing sugar per min.

Cellobiase activity: It was determined by mixing $0.8 \mathrm{~mL}$ of $1 \%$ cellobiose in $0.05 \mathrm{M}$ phosphate buffer (pH 7.0) and $0.2 \mathrm{ml}$ of diluted enzyme. The reaction mixture was incubated at $40^{\circ} \mathrm{C}$ for $10 \mathrm{~min}$, and then the glucose produced was determined using an analysis kit based on the enzyme's glucose oxidase and peroxidase, according to Blake and McLean [22]. Xylanase activity: It was measured according to Bailey et al. [23] using $1 \%$ oat xylan as the substrate. Diluted enzyme $(0.1 \mathrm{~mL})$ and $0.5 \mathrm{~mL}$ of the substrate dissolved in $0.05 \mathrm{M}$ phosphate buffer ( $\mathrm{pH} 7.0$ ), were incubated for $10 \mathrm{~min}$ at $40^{\circ} \mathrm{C}$. The reaction was terminated by boiling for $10 \mathrm{~min}$. The supernatant was analyzed for reducing sugar by DNS reagent and the absorbance was read at $540 \mathrm{~nm}$. A standard curve of d-xylose was used as reference. Each unit of xylanase activity (U) was the amount of activity, which released $1 \mu \mathrm{mol} d$-xylose $\min ^{-1}$.

\subsection{Pretreatment of rice straw}

Crushed rice straw was pre-treated with $1.5 \%$ sodium hydroxide at solid: liquid ratio $1: 20$ at $121^{\circ} \mathrm{C}$ for $30 \mathrm{~min}$. after cooling the alkali was neutralized with $2.5 \% \mathrm{HCl}$ to $\mathrm{pH} 6$. The solid treated substrate was filtered through cheese clothes, washing several 
times with water, and finally dried in oven at $70^{\circ} \mathrm{C}$ [18].

\subsection{Enzymatic saccharification of rice straw to produce Fermentable Reducing Sugars}

Aspergillus fumigatus mutant-17 crude enzyme was used to hydrolyze alkali treated rice straw as follows: $5 \mathrm{~g}$ rice straw in $250 \mathrm{ml}$ conical flask was

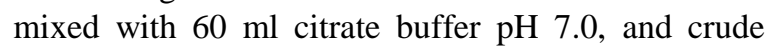
enzyme was added at $2 \mathrm{ml} / \mathrm{g}$ substrate. Then the total volume of the mixture was increased by citrate buffer pH 7.0 to $100 \mathrm{ml}$. One drop of toluene was added to prevent contamination. These flasks were incubated in water shaking bath adjusted at $40^{\circ} \mathrm{C}$ and $75 \mathrm{rpm}$. One $\mathrm{ml}$ of the reaction mixtures withdrawn at different time intervals, to determine the released reducing sugars. The percentage saccharification was calculated according to the equation of Spano et al. [24] as follows: Total reducing sugars divided by weight of substrate multiply by $0.9 * 100$.

\subsection{Chemical analysis of dry matter of SBP}

To determine dry matter (DM) loss, the difference between dry weight before and after fermentation was calculated and designated as a percentage of initial weight. Acid detergent fiber (ADF) and neutral detergent fiber (NDF) were estimated by the detergent system method. Hemicellulose contents were estimated as the difference between NDF and $\mathrm{ADF}$, while the difference between acid detergent fiber $\mathrm{ADF}$ and acid detergent lignin ADL was represented the cellulose content. Ash was carried out on dried sample at $105^{\circ} \mathrm{C}$ by ignition three samples each $50 \mathrm{~g}$ in muffle furnace at $800^{\circ} \mathrm{C}$ for $5 \mathrm{~h}$, and the residual ash was calculated as a percentage (\%) from the dried initial weight according to AOAC (1970) [25].

\section{Results and discussion}

3.1. Genetic identification of the fungus

The isolated fungal strains NRCF122 was identified genetically by DNA extraction, amplification and sequencing using 2 primers. The sequence of $18 \mathrm{~S}$ rRNA gene for the fungal strains NRCF122 was identified and aligned with other existed sequences available in the GeneBank database using BLAST tool (http://www.blast.ncbi.nlm.nih.gov/Blast), to identify the similarity score. The results confirmed a very close similarity of the obtained gene sequence for NRCF122 with $95.53 \%$ homology with Aspergillus fumigatus strain VV11. The phylogenetic tree for the
NRCF122 strains was constructed using the neighbor-joining method (Fig. 1) by MEGA 7 program according to Kumar et al. [26]. Based on the DNA sequence analysis, the NRCF122 strain was identified as Aspergillus fumigatus isolate NRCF122, and the sequences was deposited in GenBank under the accession no. MT318341.

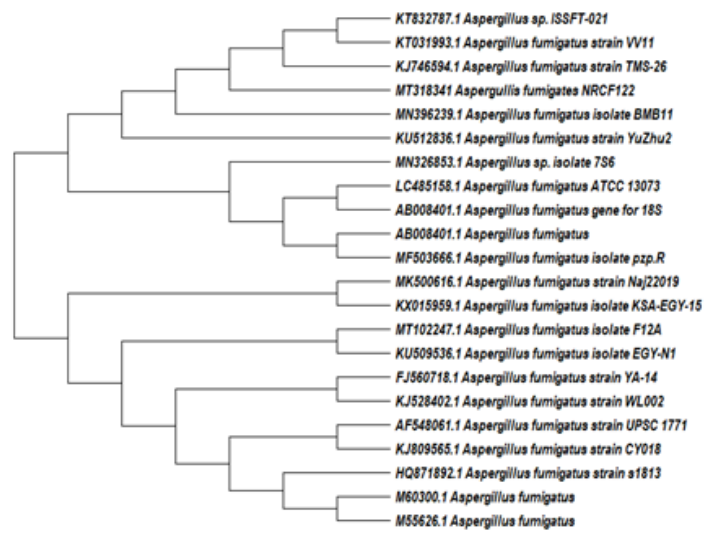

Fig. 1. Constructed phylogenetic tree for Aspergillus fumigatus isolate NRCF-122

3.2. UV-Mutagenesis for A. fumigatus NRCF122 alkaline cellulase enhancemen

Mutagenesis using UV as a physical method for enhancement enzymes production from different fungal strains was studied by many workers in scientific field [27-29]. Fig (2) showed that UVmutagenesis play a critical role in alkaline cellulase production enhancement. After the exposure of the fungus spore to $\mathrm{UV}$ for $1 \mathrm{hr}$ the enzyme activity reached 1.4-fold more than the mother-isolate. The alkaline cellulase activity of the mutant strain was $54.6 \mathrm{IU} / \mathrm{g}$, compared to $30 \mathrm{IU} / \mathrm{g}$ for the mother isolate. Many authors applied UV irradiation to induce mutagenesis for upgrading cellulase production by fungi [30]. Jafari et al. [31] found that, cellulase production by A. niger enhanced by two-fold when the fungus subjected to UV source at distance $9 \mathrm{~cm}$ for 220 seconds. On the other hand, Vu et al. [30] reported that alkaline cellulase production by Aspergillus sp. SU14-M15 increased 2.2-fold than the wild type after UV-mutagenesis. 


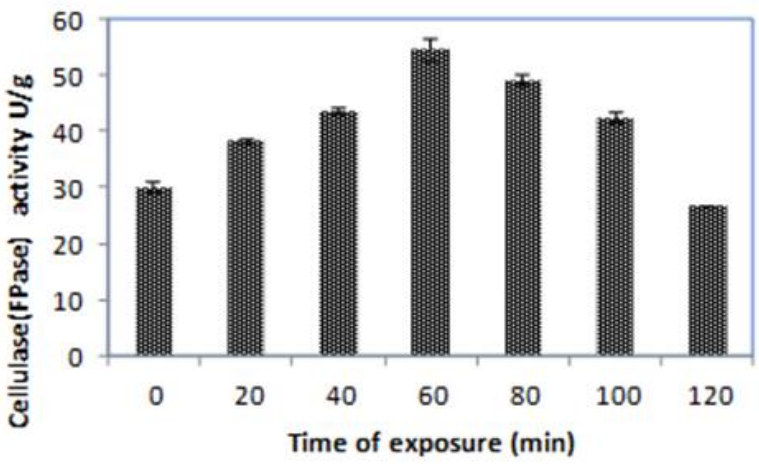

Fig. 2. Effect of UV subjected time on the production of cellulase by A. fumigatus NRCF-122 cultivated on sugar beet pulp after 4 days under solid-state fermentation solid: liquid ratio $1: 2$, initial $\mathrm{pH} 7.0$ and temperature $30^{\circ} \mathrm{C}$.

\section{3.}

Optimization of alkaline cellulase production by $A$. fumigatus mutant-17, using Sugar beet pulp "SBP" as the substrate of solid-state fermentation "SSF" technique

\subsubsection{Effect of pH on alkaline cellulase} production by A. fumigatus mutant-17

One of the most important factors influencing the fungal strain growth, enzyme production and transport of nutrients through the cell membrane is the $\mathrm{pH}$ of the medium [32]. Some enzymes produced in a narrow range of $\mathrm{pH}$, others released in wide range of $\mathrm{pH}$. The obtained results in this study revealed that, A. fumigatus mutant-17 cellulase produced in a $\mathrm{pH}$ ranged from 7-10, maximized at $\mathrm{pH}$ 10 (56.6 IU/g substrate) (Fig. 3a). The obtained results confirmed the alkalophilic nature of produced cellulase. Recently, several reports have described the important application of alkaline cellulase in many fields such as detergents, textile, paper pulping and scarification of lignocelluloses wastes. The maximum FPase production by $A$. niger was seen at $\mathrm{pH} 9$, while FPase production was achieved by a mutant of the same strain at $\mathrm{pH}$ 10. Another example of alkaline cellulase was from a mutant strain of Trichoderma asperellum RCK2011 developed through UVirradiation was at $\mathrm{pH}$ range, 4-10 [33].

3.3.2. Effect of incubation temperature on alkaline cellulase production by A. fumigatus mutant-17

Another important factor is the incubation temperature. Several reports demonstrated that incubation temperature is strongly affecting the SSF process, which varies according to the microorganism applied in fermentation process. Any change in the incubation temperature, even slight changes can affect the enzyme production. The low temperature may slow the growth of fungus and high temperature could make thermal inactivation of the enzyme. The optimum temperature for the highest production level of A. fumigatus NRCF-122 cellulase was recorded at $30^{\circ} \mathrm{C}$ with $61.2 \mathrm{IU} / \mathrm{g}$ (Fig. 3b). Cellulase production was decreased at temperatures above and below $30^{\circ} \mathrm{C}$. Many authors stated that $30^{\circ} \mathrm{C}$ is the suitable temperature for producing cellulase from $A$. oryzae ITCC-4857.01 after 7 days of incubation [34]. Another study showed that, the highest cellulase production level by Fusarium dimerum and Rhizopus oryzae was at $35^{\circ} \mathrm{C}[33]$.

\subsubsection{Effect of moisture content of the SSF} substrate $(\mathrm{SBP})$ on alkaline cellulase production by A. fumigatus mutant-17

The effect of moisture content on the cellulase production by A. fumigatus mutant-17 was studied. The results represented in Fig. (3c) revealed that the most suitable initial moisture ratio was $1: 2(\mathrm{w} / \mathrm{v}$, substrate: water). This ratio was the best ratio as it greatly enhanced the production FPase with enzyme activity reached 61.2.4 IU/g. Increasing or decreasing the moisture level in SSF may lead to undesirable results for enzyme production. The fact behind this is that, the moisture cause swelling of the substrate and facilitates utilization of the nutrients by the microorganisms. At low moisture level, this led to incomplete dissolving of nutrients in the substrate, while higher moisture content lead to reduction in the substrate porosity, thereby decreased the availability of oxygen for fungus and as a result decrease the cell growth and metabolism and inhibit the enzyme production. Abdullah et al. [36] reported that, the optimum moisture content for cellulase production by SSF Aspergillus niger ITBCCL74 was $80 \%, 70 \%$ and $60 \%$ when cultivated on rice straw, water hyacinth and corn cobs, respectively. Vu et al. [37] obtained the maximum cellulase production by $A$. terreus AUMC10138 and its mutant on corn Stover at initial moisture ratio 1:3 [38]. On the other hand, the maximum FPase production by Trichoderma asperellum RCK2011 and its mutant SR1-7 was seen at a substrate: moisture ratio 1: 2.5 [33]. 

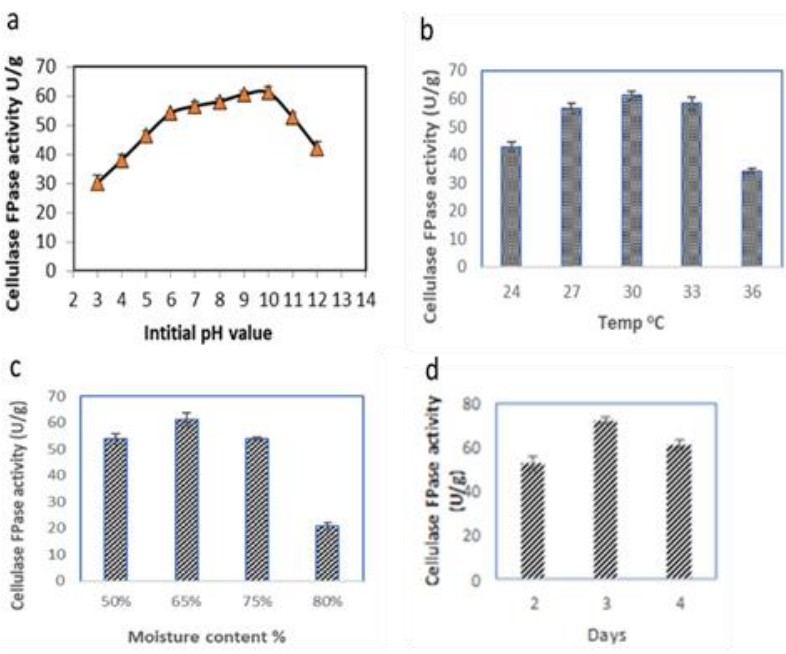

Fig. 3. Effect of initial pH (a), temperature (b), moisture content (c) and age of the fungal seed (d) on the production of alkaline cellulase by $A$. fumigatus mutant-17 cultivated on sugar beet pulp.

\subsubsection{Effect of fungal inoculum age on alkaline cellulase production by A. fumigatus mutant-17}

Fig. (3d) shows the enzyme activity of the $A$. fumigatus mutant-17 alkaline cellulase at different fungal inoculum ages. The results demonstrated that, the maximum cellulase activity was achieved when a seeding culture age is 3 days with enzyme activity $(78.8 \mathrm{U} / \mathrm{g})$. Using seeding cultures more than 3-day old displayed a remarkable decrease of cellulase yield. These results were in agreement with Isaac and Abu-Tahon [17]; they achieved the best cellulase enzyme production by thermohalophilic Aspergillus terreus AUMC 10138 by inoculation of the fermentation medium with 3 days fungal seeds

\subsubsection{Effect of fungal inoculum size (20-80\%) on} alkaline cellulase production by $A$. fumigatus mutant-17

Fig. (4a) illustrates that inoculum size is an important factor for the success of fermentation process and for efficient enzyme production. The maximum level for cellulase (as FPase) production was seen when inoculum size was $20 \%$ v/w with enzyme activity $78.8 \mathrm{U} / \mathrm{g}$. As the inoculum size increased, the enzyme production was decreased sharply due to the decrease of available oxygen amount in the fermentation medium. The quantity of moistened SBP per flask volume of culture remarkably affected amount of oxygen presence that can be utilized by the fungus mycelia.

\subsubsection{Effect of aeration on alkaline cellulase} production by $A$. fumigatus mutant-17

The maximum cellulase enzyme activity (as FPase) was $92.4 \mathrm{IU} / \mathrm{g}$ when ratio substrate-weight: flask-volume was 1:100 (Fig. 4b). Vu et al. [30] noted that substrate weight $3 \%$ is the most suitable percent when he used wheat bran to produce cellulase from Aspergillus niger. Fadel and Kahil [38] reported that $2 \%$ was the best, they used alkali treated cotton stalks for producing cellulose and hemicelluloses degrading enzyme by A. niger F-93 [39], as well as the same ratio was found by Fadel [39] when he produced xylanase from fermented sorghum flour by Trichoderma harizinum 418.

\subsubsection{Effect of nitrogen source on alkaline} cellulase production by A. fumigatus mutant-17

Nitrogen from organic or inorganic source is a vital element for protein construction of the enzyme, as well as the form of nitrogen is limiting factor for enzyme production efficiency by a specific fungus. Fig. (4c) illustrated, the effect of different nitrogen sources on FPase enzyme activity. The more promising activity was achieved using urea with activity reached $98.2 \mathrm{U} / \mathrm{g}$ solid SBP substrate. The obtained result can be discussed on the fact that urea maintains $\mathrm{pH}$ of the medium stable during the incubation period. Different nitrogen sources, as urea, were used as a nitrogen source for production of cellulase by Penicillium funiculosum, using a sequential experimental design methodology [40]. $(\mathrm{NH} 4)_{2} \mathrm{SO}_{4}$ was used for cellulase production under solid state and submerged cultures from culturing many fungal strains i.e. Trichoderma harizianum, Penicillium funiculosum, Aspergillus niger, Fusarium dimerum and Rhizopus oryyzae [35, 38, 39, 41].

\subsubsection{Incubation period}

The incubation period for production of any enzyme usually depends on the growth rate of the microorganism, substrate, and enzyme production pattern. Fig. (4d) illustrates that the cellulase (FPase) expressed the highest activity $(98.2 \mathrm{IU} / \mathrm{g})$ by the $A$. fumigatus mutant-17 after 4 days under the optimum above conditions included moisture level $65 \%, \mathrm{pH}$ 10 , and temperature $30^{\circ} \mathrm{C}$. Several reports studied the effect of incubation time on cellulase production under SSF. The highest cellulase production level by 
Fusarium dimerum and Rhizopus oryzae under optimum conditions was after 9 and 11 days, respectively [35]. Jafari et al. [31] achieved maximum cellulase From UV mutant of $A$. niger after 10 days. Raghuwanshi et al. [33] recoded maximum FPase after 4 days by Trichoderma asperellum RCK2011 and mutant strain SR1-7 under SSF. The same results were obtained by Gao et al. [42] who reported that the maximum FPase activity was after 4 days by A. terreus M11.

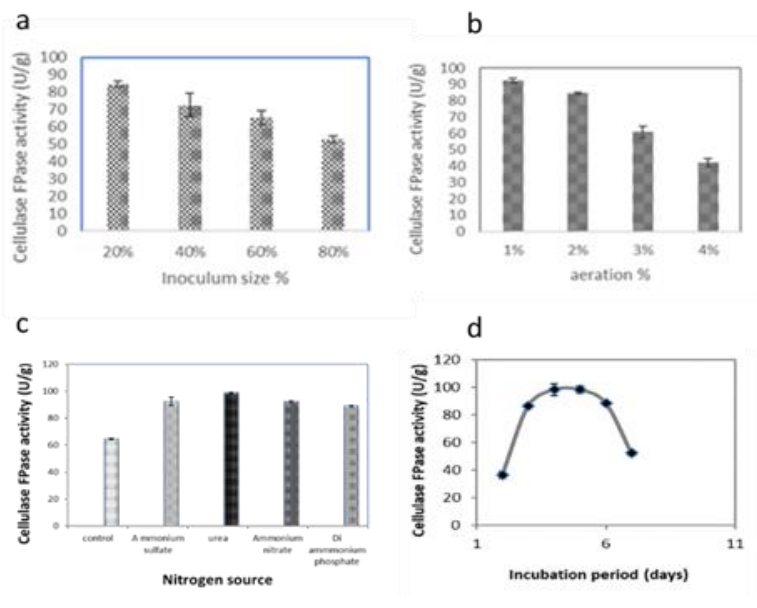

Fig. 4. Effect of inoculum size (a), Aeration (b), nitrogen source (c) and incubation period (d) on alkaline cellulase production by A. fumigatus mutant-17 cultivated on sugar beet pulp.

3.4. Lignocelluloses degrading enzymes in A. fumigatus mutant-17 SBP culture

After delignification of lignocellulosic waste by pretreatment of the main two components (cellulose and xylan hemicelluloses), the cellulases enzymes; endoglucanase "CMCase" and exo-glucanase (FPase), in combination with adequate amount of cellobiase are necessary for hydrolyzing of biopolymer cellulose to its mono monomers glucose (Fig. 5). On the other hand, xylanase is responsible for the degrading of hemicellulose to xylose. Data presented in Table (1) showed the lignocelluloses degrading enzymes measured in the fungal culture filtrate.

Table 1 Lignocelluloses degrading enzymes involved in fungal culture filtrate of A. fumigatus mutant- 17 cultivated on sugar beet pulp after 4 days under solid-state fermentation, solid: liquid ratio $1: 2$, initial $\mathrm{pH} 10.0$, inoculum size $20 \% \mathrm{v} / \mathrm{v}$ and temperature $30 \mathrm{oC}$ and urea as sole nitrogen source.

\begin{tabular}{cc}
\hline Enzyme & $\mathrm{IU} / \mathrm{ml}$ \\
\hline FPase & 4.6 \\
CMCase & 5.4 \\
Cellobiase & 8.6 \\
Xylanase & 22.8 \\
\hline
\end{tabular}

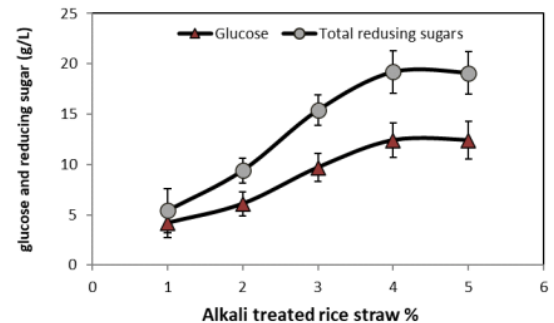

Fig. 5. Sacharification of alkali pretreated rice straw by culture filtrate of A. fumigatus NRCF-122 mutant-17 cultivated on sugar beet pulp after 4 days under solid-state fermentation, solid: liquid ratio $1: 2$, initial $\mathrm{pH} 10$, inoculum size $20 \%, \mathrm{v} / \mathrm{v}$ and temperature $30 \mathrm{oC}$ and urea as sole nitrogen source.

3.7. Feed evaluation of fermented substrate (SBP) after enzyme elution.

Table (2) showed a comparison study between the chemical composition of sugar beet pulp after and before fermentation. The data displayed a valuable upgrading in feed quality of SBP after fermentation process for lignocellulosic degrading enzymes production. The improvement included increasing of crude protein from $9.4 \%$ to $16.3 \%$, increasing in total digestible nutrient TDN from 66.4 to $69.2 \%$, and increasing growth energy performance from 3995 to 4384 kilocalories/Kg. On the other hand, decreasing of crude fiber such as ADF and NDF. Biologically treated sugar beet pulp (SBP) by fungi was evaluated as feed mixture rations for growing sheep, goats and large animals, lactating cows, lambs dairy buffalo ration, beef cattle was studied [43. 44]. Biologically treated sugar beet pulp led to upgrading crude protein to about $19 \%$ [45]. They found that feed conversion and cost of feed $/ \mathrm{kg}$ gain were the best for ration contained $25 \%$ biologically treated SBP. The results indicate that the introducing of biologically treated sugar beet pulp at rate of $25 \%$ of the concentrate feed mixture could improve feed conversion of growing lambs and was economical.

Table (2) Chemical composition of sugar beet pulp after and before fermentation

\begin{tabular}{lll}
\hline Component & $\begin{array}{l}\text { Before } \\
\text { fermentation }\end{array}$ & $\begin{array}{l}\text { After } \\
\text { fermentation }\end{array}$ \\
\hline Dry mater (\%) & 90.0 & 92.4 \\
Aflatoxin (\%) & Nil & Nil \\
Crude protein (\%) & 9.4 & 16.3 \\
Crude fiber (\%) & 22.4 & 15.2 \\
ADF (\%) & 26.6 & 20.8 \\
NDF (\%) & 44.2 & 35.2 \\
Ash (\%) & 5.4 & 5.8 \\
Cellulose (\%) & 36.6 & 32.6 \\
Gross energy (kilocalories / Kg) & 3795 & 4384 \\
Total digest nutrient "TDN" (\%) & 66.4 & 69.2 \\
\hline
\end{tabular}




\section{Conclusion}

Fungal cellulase production was optimized by studying different parameters such as (biological, chemical \& physical). The optimal conditions were: initial moisture content ratio $(1: 2(\mathrm{w} / \mathrm{v}$, substrate weight :water volume)), incubation temperature $\left(30^{\circ} \mathrm{C}\right)$, initial $\mathrm{pH}$ of solid culture $(10$, high wide range 7-10), incubation period (4 days), aeration area (1:100 ratio $((1 \%))$, SBP substrate weight : flask volume) of moistened SBP in a $250 \mathrm{~mL}$ Erlenmeyer flask, fungal inoculum (seeding) culture age (3 days), and inoculum size $(20 \%, \mathrm{v} / \mathrm{w})$. Studies were also involved the effect of nitrogen sources (urea, ammonium sulfate, di-ammonium phosphate and $\left.\mathrm{NH}_{4} \mathrm{NO}_{3}, \% \mathrm{w} / \mathrm{w}\right)$ revealed that urea is the best nitrogen source for cellulase production. As for another application (animal feed production); after fermenting of SBP for cellulase production, its crude protein content, TDN (Total digest nutrient) and Gross energy performance were increased, where as crude fiber, ADF \& NDF were decreased, upgrading the feed quality of biologically treated SBP.

\section{Conflicts of interest}

There are no conflicts to declare.

\section{Acknowledgment}

The authors would like to extend their appreciation to National research centre, Egypt for funding.

\section{References}

[1] Veliz A.T., Martínez-Hidalgo P. and Hirsch, A.M. Chitinase-producing bacteria and their role in biocontrol, AIMS Microbiology, 3, 689-705 (2017).

[2] Kumar B., Bhardwaj N., Alam A., Agrawal K., Prasad, H. and Verma, P., Production, purification and characterization of an acid/alkali and thermo tolerant cellulase from Schizophyllum commune NAIMCC-F-03379 and its application in hydrolysis of lignocellulosic wastes, AMB Express, 8,1-16 (2018).

[3] Abd El-Hady F.K., Shaker K.H., Souleman A.M.A., Fayad W., Abdel-Aziz M.S., Hamed A.A., Iodice C. and Tommonaro G., Comparative Correlation Between Chemical Composition and Cytotoxic Potential of the Coral-Associated Fungus Aspergillus sp. 2C1EGY Against Human Colon Cancer Cells. Curr. Microbiol, 74, 1294-1300 (2017).

[4] Abdel-Aziz M.S., Ghareeb M.A., Saad A.M.,
Refahy L.A. and Hamed A.A., Chromatographic isolation and structural elucidation of secondary metabolites from the soil-inhabiting fungus Aspergillus fumigatus 3T-EGY, Acta Chromatogr, 30, 243-249 (2018).

[5] Abdel-Aziz M.S., Hathout A.S., El-Neleety A.A., Hamed A.A., Sabry B.A., Aly S.E and Abdel-Wahhab, M.A., Molecular identification of actinomycetes with antimicrobial, antioxidant and anticancer properties, Comun. Sci, 10, 218231 (2019).

[6] Hifnawy M.S., Hassan H.M., Mohammed R., Fouda M.M., Sayed A.M., Hamed A.A., AbouZid S.F., Rateb M.E., Alhadrami H.A. and Abdelmohsen, U.R., Induction of antibacterial metabolites by co-cultivation of two Red-Seasponge-associated actinomycetes micromonospora sp. UR56 and Actinokinespora sp. EG49., Mar. Drugs, 18, 243 (2020).

[7] Aly S., Hathout A., El-Nekeety A., Hamed A., Sabry B., Abdel-Aziz M. and Ghareeb, M., Egyptian bacterial exhibiting antimicrobial and antiaflatoxigenic activity J. Appl. Pharm. Sci, 6, 001-010 (2016).

[8] Aly S.E., Abdel-Wahhab M.A., El-Neekety A.A., Abdel-Aziz M.S., Hathout A.S., Hamed A.A., Sabry B.A. and Ghareeb M.A., Molecular identification of newly isolated non-toxigenic fungal strains having antiaflatoxigenic, antimicrobial and antioxidant activities, Der Pharma Chem, 8, 121-134 (2016).

[9] El-Bendary M.A., Afifi S.S., Moharam M.E., Abo El-Ola S.M., Salama A., Omara E.A., Shaheen M.N.F., Hamed A.A. and Gawdat N.A., Biosynthesis of silver nanoparticles using isolated Bacillus subtilis: characterization, antimicrobial activity, cytotoxicity, and their performance as antimicrobial agent for textile materials, Prep Biochem Biotechnol., 51, 54-68 (2020).

[10] Eskander D.M., Atalla S.M.M., Hamed A.A., ElKhrisy E.D.A. Investigation of Secondary Metabolites and its Bioactivity from Sarocladium kiliense SDA20 Using Shrimp Shell Wastes, Pharmacogn. J., 12, 636-644 (2020).

[11] Ghareeb M.A., Hamed M.M., Saad A.M., AbdelAziz M.S., Hamed A.A. and Refahy L.A., Bioactive secondary metabolites from the locally isolated terrestrial fungus. Penicillium sp. SAM16-EGY. Pharmacogn., Res., 11, 162-170. (2019).

[12] Hamed A.A. Soldatou S., Qader M.M., Arjunan S., Miranda K.J., Casolari F., Pavesi C., Diyaolu O.A., Thissera B., Eshelli M., Belbahri L., 
Luptakova L., Ibrahim N.A., Abdel-Aziz M.S., Eid B.M., Ghareeb M.A., Rateb M.E. and Ebel R., Screening fungal endophytes derived from under-explored Egyptian marine habitats for antimicrobial and antioxidant properties in factionalised textiles, Microorganisms. 8, 1617 (2020).

[13] Hamed A.A., Abdel-Aziz M.S., Fadel M. and Ghali M.F., Antidermatophytes from bioactive secondary metabolites of local Streptomyces spp. J. Innov. Pharm. Biol. Sci. 3, 155-165 (2016).

[14] Hamed A.A., Kabary H., Khedr M. and Emam A.N., Antibiofilm, antimicrobial and cytotoxic activity of extracellular green-synthesized silver nanoparticles by two marine-derived actinomycete., RSC Adv., 10, 10361-10367 (2020).

[15] Bajar S., Singh A.R. and Bishnoi N.R., Exploration of low-cost agro-industrial waste substrate for cellulase and xylanase production using Aspergillus heteromorphus. App. Water Sci., 10, 153 (2020).

[16] Shahriarinour M. and Ramanan R.N., Purification and characterization of extracellular cellulase main components from Aspergillus terreus. Bio. Res., 10, 4886-4902 (2015).

[17] Isaac G.S. and Abu-Tahon M.A., Enhanced alkaline cellulases production by the thermohalophilic Aspergillus terreus AUMC 10138 mutated by physical and chemical mutagens using corn Stover as substrate., Braz. J. Microbiol., 46: 4 (2015).

[18] Ismail S.A. and Hassan, A. A., Optimizing the production of rice straw hydrolytic cellulase under solid-state fermentation using Aspergillus terreus RS2., Egypt. Pharmaceut. J., 19, 717(2020).

[19]Bai S., Kumar M.R., Kumar D.J.M., Balashanmugam P., Kumaran M.D.B. and Kalaichelvan P.T. Cellulase production by Bacillus subtilis isolated from cow dung., Arch. Appl. Sci. Res., 4, 269-279 (2012).

[20] Miller G.L., Use of dinitrosalicylic acid reagent for determination of reducing sugar. Anal. Chem., 31, 426-429(1959).

[21] Mandels M., Hontz T. and Nystrom C., Enzymatic hydrolysis of waste cellulose., Biotechnol. Bioeng., 16, 1471-1493(1974).

[22] Blake D.A. and McLean, N. V., A colorimetric assay for the measurement of D-glucose consumption in cultured cells., Analytical Biochemistry, 177, 156-160(1989).

[23] Bailey M.J., Biely P. and Poutanen K., Inter laboratory testing of methods for assay of xylanase activity., J. Biotechnol., 23, 257-270
(1992).

[24] Spano L., Medeirps J. and Mandels M., Enzymatic hydrolysis of cellulose wastes to glucose., Resource Recovery and Conservation, 1, 279-294 (1976).

[25]AOAC, Official Methods of Analysis of the Association of Official Analytical Chemists, 11th ed., vol. 1. AOAC, Washington, DC: 69-90 (1970).

[26] Kumar S., Stecher G. and Tamura K., MEGA7: Molecular evolutionary genetics analysis, version 7.0 for bigger datasets., Mol. Biol. Evol., 33, 1870-1874(2016).

[27] Vu V.H., Pham T.A. and Kim K., Fungal strain improvement for cellulase production using repeated and sequential mutagenesis., Mycobiology, 37, 267-271(2009).

[28] Hamed A.A., Khedr M. and Abdelraof M., Activation of LacZ gene in Escherichia coli DH5 $\alpha$ via $\alpha$-complementation mechanism for $\beta$ galactosidase production and its biochemical characterizations., J Genet Eng Biotechnol., 18, 80 (2020)

[29] Hamed A.A., Khedr M. and Abdelraof M., Molecular characterization of alkaline proteasecoding gene from Bacillus licheniformis MK90 mutants with biofilm inhibitory activity, Egypt Pharmaceut J., 18, 419-433 (2019).

[30] Vu V.H., Pham T.A. and Kim K., Improvement of a fungal strain by repeated and sequential mutagenesis and optimization of solid-state fermentation for the hyper-production of rawstarch-digesting enzyme, J. Microbiol. Biotechnol., 20, 718-726 (2010).

[31] Jafari N., Jafarizadeh H.M., Hamzeh M.M., and Adibpour, M., Optimization of UV irradiation mutation conditions for cellulose production by mutant fungal strain of Asperigillus niger through solid-state fermentation, Green process synth, 6, 333-340 (2017).

[32] Juhász T., Szengyel Z., Szijártó N. and Réczey K., Effect of $\mathrm{pH}$ on cellulase production of Trichoderma reesei RUT C30, Appl Biochem Biotechnol. 113, 201-211 (2004).

[33] Raghuwanshi S., Deswal D., Karp M. and Kuhad R.C., Bioprocessing of enhanced cellulase production from a mutant of Trichoderma asperellum RCK2011 and its application in hydrolysis of cellulose. Fuel, 124, 183-189 (2014).

[34] Begum M.F. and Absar N., Purification and Characterization of Intracellular Cellulase from Aspergillus oryzae ITCC-4857.01, Mycobiology. 37, 121-7 (2009).

[35] Ahmed M.M., Soad A. E. and Magdi A. E., 
Cellulolytic activity of cellulose-decomposing fungi isolated from Aswan hot desert soil, Egypt. Journal of Biological Studies (JBS), 1, 35-48 (2018).

[36] Abdullah B., Maftukhah S., Listyaningrum E. and Faradhiba F., Effect of some variable in cellulase production by Aspergillus niger ITBCCL74 using solid state fermentation. IOP Conf. Series Materials Science and Engineering, 316, 012066 (2018).

[37] Vu V.H., Pham T.A. and Kim K., Improvement of fungal cellulase production by mutation and optimization of solid-state fermentation, Mycobiology, 39, 20-25(2011).

[38] Fadel M. and Kahil T., Production and application of cellulose and hemicellulose degrading enzymes from cotton stalks by fungi in solid-state fermentation, Egypt. J. Biotechnol. 125-137 (2003).

[39] Fadel M., Production physiology of cellulase and $\beta$-glucosidase enzymes of Aspergillus niger grown under solid state fermentation conditions, Online Biological Sci., 1, 64-75 (2000).

[40] Maeda R.N., da Silva M.M., Santa-Anna L.M. and Pereira N.J., Nitrogen source optimization for cellulase production by Penicillium funiculosum, using a sequential experimental design methodology and the desirability function, Appl. Biochem. Biotechnol., 161, 411422 (2010).

[41]Fadel M. and Foda M.S., Production of the fungal cellulases under static condition for saccharification of lignocelulosic wastes in Egypt, J. Microbiol., 28, 36-47 (1993).

[42] Gao J.H., Zhu W.D., Yuan M., Guan F. and Xi Y., Production and characterization of cellulolytic enzymes from the thermos acidophilic fungal Aspergillus terreus M11 under solid-state cultivation of corn Stover, Bioresour. Technol., 99, 7623-7629 (2008).

[43] Abedo A.A., El-Badawi A.Y., El-Ashary M.A., Fadel M. and Helal F.I.S., Microbial protein enrichment of sugar beet pulp by aerobic fermentation, Egyptian J. of Nutrition and Feeds, 10, 553-568 (2007).

[44]E1-Ashry M.A., El-Sayed E.L.M., Fadel M., Metwally E.L.M. and Khorshed M.M., Effect of chemical and biological treatments of some cropresidues on their nutritive value: 2- Effect of biological treatments on chemical composition and in vitro disappearance, Egyptian J. of Nutrition and Feeds, 5, 43-54 (2002).

[45] Abedo A.A., El-Ashry M.A., EI-Badawi A.Y., Halal F.I.S. and Fadel M. Effect of feeding biological treated sugar beet pulp on growth performance of sheep, Egyptian J. of Nutrition and feed, 8, 579-590(2005). 